\title{
METODISTE, METODISME EN SENDING
}

\section{Vooraf}

So pas het by Pro Rege, Potchefstroom, 'n waardevolle en belangrike studie oor die Metodisme verskyn, nl. „Revival of Reformasie” van die hand van proff. G. C. P. van der Vyver, P. J. Coetzee en P. W. Buys. Wat hier volg sluit daarby ten nouste aan. Ek vereenselwig my ook ten volle met hulle kritiek op die Metodisme as geestesrigting en herhaal dit daarom, sover moontlik, nie in onderstaande tentatiewe studie nie. Ek noem dit tentatief omdat dit maar ' $n$ begin is, wat later vollediger uitgewerk moet word.

\section{„Wie nie teen ons is nie, is vir ons"}

„... my gedagtes is nie julle gedagtes nie, en julle weë is nie my weë nie, spreek die Here. Want soos die hemel hoër is as die aarde, so is my weë hoër as julle weë en my gedagtes as julle gedagtes" (Jes. $55: 8,9$ ).

Dit is presies die geval in die gesprek van Christus met sy dissipels in Mark. 9:30-41 en Luk. 9:46-50. Hulle is bekommerd oor wie van hulle die grootste in die koninkryk van die hemel is en beskou dit as hulle heilige plig om iemand ,wat ons nie volg nie" te belet om in die Naam van Christus duiwels uit te dryf. Hierteenoor stel Jesus: „As iemand die eerste wil wees, moet hy die laaste van almal en almal se dienaar wees" en "Moet hom nie belet nie, want daar is niemand wat ' $\mathrm{krag}$ in my Naam sal doen en gou van my sal kan kwaadspreek nie, want wie nie teen ons is nie, is vir ons".

Skynbaar staan hierdie laaste woorde direk teenoor dié van Matt. 12:30 en Luk. 11:23 waar Jesus baie skerp sê: „Hy wat nie met My is nie, is teen My; en hy wat nie saam met my versamel nie, verstrooi". In die eerste plek moet ons by die twee uitsprake daarop let dat Jesus in die een geval praat van "ons" en in die ander net van Homself. Volgens sommige geld lg. uitspraak veral by selfondersoek: ek kan en mag Jesus nooit halfhartig dien en volg nie. Ek moet steeds waak en bid en steeds die geeste op die proef stel of hulle uit God is ( 1 Joh. $4: 1$ ), terwyl die eg. uitspraak veral geld in die beoordeling van ander mense buite eie kring. Met ander woorde Jesus Christus verwag absolute duidelikheid en helderheid in ons verhouding teenoor Hom en in die beoordeling van die geeste, maar ootmoedige versigtigheid en barmhartigheid in ons beoordeling van Christene wat nie aan ons eie kring behoort nie. Al te maklik mag ons selfs nie die waarskuwing van Gamaliël in Hand. 5 vergeet nie. Daarom stel ons hierbo 'n dubbele hoof: die Metodiste as mense, wat saam met ons die Naam van Christus bely en deur wie God ook groot dinge tot stand gebring het, moet in liefde en barmhartigheid beoordeel word; die metodisme as geestesrigting moet skerp en suiwer ontleed en waardeer word, positief 
of/en negatief in verband met die sendingtaak van die kerk van Christus.

Hier wil ons aansluit by die slotparagraaf van Totius se proefskrif, „Het Methodisme” (1903): „Aan die einde van my beskouinge gekom, wens ek ten slotte nog daarop te wys dat dit in hierdie dissertasie hoofsaaklik my bedoeling was om die Metodisme van Gereformeerde standpunt uiteen te sit en te beoordeel. Dit is egter nie gedoen om daarmee die groot werk van God wat deur middel van hierdie geestelike beweging tot stand gekom het, te misken nie. Wesley en Whitefield was in die donker Deïstiese eeu die instrumente in die hand van God om die Christendom uit 'n diepe en sondige slaap wakker te roep, en nog steeds klink sowel oor die Christelike erf as oor die velde van die heidendom hulle magtige woord na. Nie alleen dank Amerika sy teenswoordige Christendom grotendeels aan die werk wat deur hierdie manne begin is nie, maar hulle aksic het mede die stoot gegee aan die reusagtige sendingwerk van ons tyd. Ook het veral die Metodisme die oë geopen vir die node van 'n buitekerklike proletariaat, wat in godsdiens- en sedeloosheid weggesink het. En waar in die boesem van die Christelike kerk die droom van geestelike lewc in ortodoksisme en rasionalisme versand, daar is 'n Revival na Metodistiese trant dikwels die enigste redmiddel.

So lê dan ook hier die goeie en die kwaad deureengestrengel en bring dit ons tot stille aanbidding van Hom wat die manne verwek na sy welbehae en deur hulle swak en veelsins met sonde bevlekte pogings sy werk oplei na die voorstelde doel".. (Kursivering van my, DM.)

In die kerkgeskiedenis, binne-in die kerk, sien ons hierdie waarhede al te duidelik; in die sendinggeskiedenis nog duideliker wat ook op sigself ' $n$ wonder van God is. Bloot-menslik gesproke lyk God se sendingmetode (met die nodige eerbied) uiters swak en ondoeltreffend: Hy stuur die goud en diamante van sy Evangelie oor die wêreld heen in stukkende papiersakkies op eenvoudige donkiekarretiies of in lekkerige roeiskuitjies. Kon God sake nie beter gereël het nie deur bv. die heilige engele te stuur en meteens somar gelyktydig oor die hele wêreld die Evangelie presies eners laat verkondig het nie? Waarom so stadig, omslagtig, verwarrend werk deur en met sukkelaar-sondaarmensies wat soos taai stroop op 'n koue dag alte stadig versprei. Geen wonder dat daar na twintig eeue soveel verwarring en verdeeldheid in die Kerk is nie en nog miljoene is wat die Evangelie nog nie gehoor het nie.

Dat God dit wel só gedoen het en nog doen rus in sy welbehae en dit is die Wonder van die sendinggeskiedenis. Hieraan en hierin het die Metodiste wat die mens betref 'n reuse-aandeel gehad. Ons probeer dan eers kortliks aandui wat hulle gedoen het; ten tweede wil ons positief die redes probeer gee waarom hulle soveel bereik het, en ten derde aan te dui waarin hulle o.i. tekort geskiet het.

Wat het die Metodiste bereik?

Wat die Metodiste bereik het verdien nog as sendinggeskiedenis 
oorspronklike wetenskaplike navorsing. „Dit is iets anders as die openbaringsgeskiedenis wat ons in die Skrif ontvang en ook iets anders as dogmatiek en missiologie, hoewel daarmee ten nouste verwant en direk daarby betrokke, teoreties en prakties". ${ }^{3}$ Hier kan ons net enkele hoofsake noem, veral soos ons dit vind in die werke van K. S. Latourette saam met enkele ander werke. ${ }^{4}$ Verder aanvaar ons J. H. Bavinck se indeling van die sendinggeskiedenis. Hy noem vyf hoofperiodes:

(i) die spontane periode, waarin elke Christen eintlik sendeling was;

(ii) die tydperk van die Corpus Christianum waarin die staat gekersten geraak het en dan self ook direk en indirek die sendingwerk van die hele, sg. Christelike gemecnskap, op allerlei maniere gedra en probeer bevorder het - vanaf die tyd van Konstantyn die Grote tot ongeveer die jaar 1700;

(iii) die tydperk van die Piëtisme en verwante strominge, waaronder ook die Metodisme voorkom - ,Men trekt zich terug op het korte front, de eenvoudige verkondiging van de boodschap. Men staat sceptisch en veelal afwijsend tegenover het cultuurproblemen en verwacht ook weinig heil van de Kerk. Er speelt door het zendingsgebeuren een sterker eschatologisch moment dan in de vorige periode meestal het geval was".5 (Kursivering van my, DM.);

(iv) die negentiende ceu, die sg. Wondereeu van die sending, waarin veral ' $n$ menigte van sendinggenootskappe en -verenigings 'n wêreldomvattende en deurslaggewende rol speel, 'n tydperk waarin die tekorte van die Piëtisme en geesgenote raakgesien word en meer aandag gegee word aan volksopbou, kultuur en die betekenis van die nie-Christelike religieë;

(v) die moderne tyd van die ekumeniese bewegings.

Ons beperk ons hier tot die kerklike aktiviteite op sendinggebied van Metodiste in die derde, tot vierde en tot die vyfde periode wat Bavinck onderskei.

Vanaf 1813 word die eerste sendinggenootskappe deur die Metodiste gestig, en in 1817-1818 word hulle gekoördineer in die Wesleyan Missionary Society. Voor die tyd is al baie sendingwerk onder die heidene gedoen hoewel die Metodiste hulle tot 'n baie groot mate toegelè het op Home Mission, wat ons „evangelisasie" sou noem. Waar hulle die verbondsgedagte eintlik heeltemal tersyde gelaat het en op die individu gekonsentreer het, moet ons hulle tog ter ere gee dat hulle geweldig baie aandag en tyd bestee het aan wat ons verwaarloosde verbondskinders sou noem. Deur die geweldige groot binnelandse migrasies in Europa en Engeland ten gevolge van die Industriële Revolusie het oneindig baie mense eenvoudig geografies en geestelik weggeraak van die kerk af. Dieselfde het op groot skaal gebeur in die emigrasie vanuit die Europese staatskerklande na die state in Noord-Amerika. Ons mag, veral hier. in Suid-Afrika waar die toestande anders was, nie vergeet dat onder immigrante in Noord-Amerika aanvanklik slegs 'n kleine $5 \%$ werklike kerklidmate was. Op die orige $95 \%$ is die Home Mission gerig, net soos mettertyd die wêreldwye Sunday School-beweging toege- 
spits is op die geestelik-verwaarloosde jong. Ook hierin het die Metodiste 'n baie groot rol gespeel.

Die aanvanklike beginsels van die Wesleybroers $\mathrm{nl}$. respristinasie van die Oudheid, asketisme (wêreldmyding) en mistisisme sou mens laat verwag dat hulle hulle sou terugtrek in die eensaamheid van die klooster. Lynreg daarteenoor kies hulle die wêreld en probeer hulle mettertyd 'n leër rekruteer om daarmee die wêreld te verower vir Jesus Christus. ${ }^{6}$ Hulle het 'n groot mate daarin geslaag om 'n Christelike wêreldbeweging op tou te sit en aan die gang gehou soos blyk uit die feite.

In 1760 begin die Metodiste met vergaderings in New York; nie lank daarna begin $R$. Strawbridge in Maryland en wedywer met New York om vernaamste sentrum van die Metodiste in Amerika te wees. Whitefield besoek Amerika herhaaldelik vanaf 1740 en bevorder die sg. „Great Awakening" van die agtiende eeu in Amerika wat ook begin oorloop na die Negers en Indiane. Metodisme bereik die Wes-Indiese Eilande in 1760. In Antigus ontstaan 'n sterk Metodistiese Vereniging onder die Negers. Hier begin Thomas Coke in 1786 en in 1814 tel die Metodiste hier 17 000. In 1818 gaan Charles Cook as Metodiste-sendeling na Frankryk, werk met vrug en organiseer daar 'n Fransnasionale Metodisteverband. In Duitsland word daar 2300 Metodiste getel ten gevolge van die sendingwerk van C. G. Müller. Vanuit Amerika word ook sendelinge na Duitsland gestuur „sodat daar in 191428000 lidmate is. Hiervandaan versprei die Metodisme na Switserland en Oostenryk. Na Swede gaan ook Amerikaanse sendelinge, sodat die Metodiste 17637 tel in 1913. In 1850 ontstaan 'n Metodistebeweging in Noorweë; in 1893 is daar 4500 lede. In Denemarke word daar na 1849 ook sending gedoen; in Finland tel die Metodiste in 19131281 ten gevolge van arbeid uit Swede en Amerika. In die Verre Wilde Weste van Amerika bereik die Metodiste die kerkloses en stig die Methodist Episcopal Church. Ten gevolge van die „Camp-meetings” is daar groot groei. Onder die Negers, veral in die Suide van Amerika, versprei die Metodisme saam met die Baptisme baie vinnig. In baie gevalle vorm die Negers hulle eie kerkverband, later genoem die African Methodist Episcopal Church en die African Methodist Episcopal Zion Church, gelei deur Negers self. In 1860 is omtrent 520000 Negers lidmate van Christelike kerke. In 1916 was dit 4602805 . Hiervan was $231 \%$ Metodiste, wat saam met die Baptiste $87 \%$ van die totaal uitmaak. In 1807 word die eerste Indiaan tot die Metodisme bekeer en in 1821 word William Capers die eerste sendeling onder hierdie volk. In 1884 word die opwekkingsprediker William Taylor biskop vir Afrika van die Methodist Episcopal Church. Hy werk in SuidAfrika en lei groot sendingwerk in Angola. Ook in Nigerië werk die Wesleyane. In 1883 het W. B. Cox die eerste sendeling van die Methodist Episcopal Church geword. In 1823 het die eerste Metodistesendelinge ook in Zambië verskyn. In 1838 word die eerste Metodistekapel in Australië gebou. Hulle werk in Kanada, Suid-Amerika, Nieu-Seeland, en op groot skaal en met vrug in Indië, Burma, Malaya, Sjina, Japan, Korea en Ceylon. In die tyd van die Fascisme 
doen Amerikaanse Metodiste ook sending in Italië.

In 1816 begin eerw. B. Shaw as eerste Metodistesendeling aan die Kaap. Hy leer dadelik Afrikaans of Hollands en preek later in dié taal. Hy gaan werk by Leliefontein in Kammiesberge. In 1818 kom eers J. Archbell by en die werk gaan voort, met 'n poging by Warmbad, SWA, wat misluk het. William Shaw werk later in Kaffraria, waar ook die bekende Bantoetaalkundige W. B. Boyce optree. Archbell gaan werk onder die Barolong naby Thaba 'Nchu. In 1866 werk W. Taylor by King William's Town en hou opwekkingsdienste onder die Khosas en in Natal. Statisties en andersins onderskei die Metodiste nie blankes en nie-blankes in hulle werk nie.

In 1886 kom hulle tot die instuering van 'n cie, selfstandige Suid-Afrikaanse Conference en daarna word ook 'n eie South African Missionary Society gestig, 'n vereniging wat mettertyd meer sendelinge as enige van die ander genootskappe in Suid-Afrika in die veld het. Die vrug hiervan sien ons o.a. in die feit dat die Metodistekerk in 1955 die grootste aanhang van alle kerke, $12,9 \%$, onder die Bantoe van Suid-Afrika het. Die African Methodist Episcopal Church van Amerika is reeds voor die Anglo-Boereoorlog deur President Paul Kruger in Transvaal erken.

Volgens die World Christian Handbook (1957) is daar ongeveer 3 miljoen Metodistelidmate op die verskillende sendingvelde dwarsoor die wêreld. Volgens Algra word die aantal lede van die Anglikaanse Kerk bereken op 4 miljoen en die ledetal van die Engelssprekende Vrye Kerke op 21 miljoen. Ons het ons met opset in bostaande steekproefgegewens tot die Metodistekerke beperk, behalwe in die laaste sin hierbo. Die invloed van die Metodisme as beweging, buitekant die engere kring van eie kerkverband, was geweldig, o.a. ook omdat dit aansluiting gevind het by wat Algra die Vrye Kerke noem. Hulle het die gedagtegang van die sg. interdenominasionalisme saam met die godsdienstige verenigingswese laat sterk opbloei in die negentiende eeuse sending. Hierdie invloed werk deur in sulke magtige wêreldfigure as John R. Mott, 'n Amerikaanse Metodis, stigter en bouer van die New Young Men's Christian Association en die Wêreldfederasie van Christenstudenteverenigings. Mott was voorsitter van die eerste drie groot wêreldsendingkonferensies (Edinburgh 1910, Jerusalem 1928 en Tamberam 1938). Volgens Van der Waal is die wêreldwye CSV deur middel van manne soos Visser ' $t$ Hooft een van die grootste invloede in die totstandkoming en ontwikkeling van die Wêreldraad van Kerke.

Wie Wesley's en hulle volgelinge het dus voorwaar die wêreldin getrek en veel bereik in wat hulle geglo het die regte verkondiging van Evangelie van Jesus Christus te wees. Dat hulle soveel vermag en bereik het, is sekerlik nie net te danke aan blote mensewerk nie. Volgens die kriteria van Gamaliël moet ons met Totius saamstem dat ons hier te doen het met 'n grootse werk van God, wat egter nie beteken dat dit sondeloos cn volmaak was in sy mensemateriaal en -gedagtegang nie. 
Waarom het die Metodiste en Metodisme só ver en só goed gevorder?

Op hierdie vraag kan ons hier geen histolies-gedokumenteerde en wetenskaplik-verantwoorde antwoord gee nie. Uit die historiese bronne wat ons wel kon raadpleeg, kan ons slegs enkele hoofgedagtes na vore bring, om te probeer verklaar waarom 'n beweging wat by uitstek as Revivalbeweging was tog nog standhou en voortwerk oor mecr as twee eeue.

\section{Arminianisme}

'n Oppervlakkige en algemeen-aanvaarde verklaring is dat juis Wesley se Arminianisme en radikale verwerping van die uitverkiesingsleer die eintlike dryfkrag was. Die optimistiese geloof aan die goeie in elke mens en die aanvaarding van die verantwoordelikheid dat juis ék aan hom so gou moontlik die Evangelie moet verkondig, anders gaan hy verlore, het seer seker 'n deurslaggewende rol gespeel. Latourette sê dat die Calviniste en Baptiste in hulle sending- en bekeringswerk ,belemmer" is deur die uitverkiesingsleer, terwyl juis die Wesleyane van hierdie „belemmering" bevry is deur hulle Arminianisme. ${ }^{8}$ Hierdic geloof het by sy aanhangers ' $n$ brandende ywer en dringende haas veroorsaak, sodat hulle byna onkeerbaar die wêreld ingestorm en onder die aller moeilikste omstandighede volhard en uitgehou het. Vir diegene wat saam met die Gereformeerdes volgens Skrif vashou aan die uitver. kiesingsleer is dit 'n praktiese beskaming en teoreties 'n radikale uitdaging - om aan te toon dat juis die handhawing van die uitverkiesingsleer bevorderlik is vir sending en evangelisasie. $\mathrm{Al}$ sou ons Fil. 1:15-19 (met toepaslike veranderinge) hier kon laat geld as Skriftuurlike kritiek op die dwaling van Arminianisme, moet ons tog aan die ander kant erken dat die Evangelie wel gepreek is, op die sendingvelde van die wêreld en onder die kerklose proletariaat van die Industriële Revolusie. Oral het dit met 'n weergalose dryfkrag en volharding geskied. Hiervoor moet ons God dank.

\section{Oplewinge}

Hierdie dryfkrag en volharding het soms opwekkings en revivals veroorsaak, maar meer dikwels het die sg. ontwakings eienaardigspontaan ontstaan. Dan het die Metodiste wel deeglik daarvan gebruik gemaak, maar kan hulle hoegenaamd nie met reg as die oorsaak daarvan bestempel word nie. Latourette toon aan dat daar, soms oor groot dele van die wêreld gelyktydig, soms weer sporadies op sekere tye en in sekere lande en onder sekere volke, sulke "Awakenings" voorgekom het - in Uganda, in Indonesië, in Khosaland, in Thailand, in die Wilde Weste van Amerika, en so ook in die helfte van die negentiende eeu ook in Suid-Afrika veral in die geledere van die Nederduitse Gereformeerde Kerk. Laasgenoemde beweging loop in 1861 uit op die instelling van die bekende Pinksterbidure.9 Dit is asof daar op sekere tye golwe van geestelike opwelling oor volke en die kerk speel, met die gevolg dat daar tot 'n 
matc nuwe lewe kom. Dit kan verskillend gekanaliseer en beoordeel word. Dit is opvallend dat parallel met, en ook antiteties teenoor genoemde Pinksterbidure juis in dieselfde tyd (1859) die Gereformeerde Kerk in Suid-Afrika herstig is.

So wys Latourette daarop dat daar dikwels byna gelyktydig antitetiesc oplewinge binne Protestantse Kerke en die Rooms-Katolieke Kerk voorgekom het. In die geskiedenis van die kerk werk magte en kragte veel groter as die mans of enige kerklike verband. Die Kerk moet hom voor God verantwoord hoe hy sodanige kragte of magte gebruik of misbruik. In dié sin beskryf Algra dan ook die ,wonder" van die negentiende eeu ,van vrije kerken en kleine luyden".

\section{Imperiale Christendom}

In 'n baie belangrike, raak en waardevolle studie ontleed B. Spoelstra die rol van kolonialisme in die sending. ${ }^{10}$ Hy toon aan hoedat die Christen-Europeër en die Christen-Boer hierin dikwels teenoor mekaar te staan gekom het. Neill toon aan dat die Christelike Kerk aan die einde van die sestiende eeu byna heeltemal ge-Europeaniseer was, met die gevolg dat die sendinguitbreiding gedra en helaas ook besoedel is deur blote Europese militêre, tegniese en handelsuitbreiding van Empires oor die hele wêreld heen. Kolonialisme is dikwels gesien as Christelike plig en roeping, en berus, volgens Spoelstra, op die idee van kultuursupremasie en kultuurmonopolie. Hierin het die Angel-Saksiese wêreld, die ou Engeland en die nuwe Noord-Amerika, op verskillende maniere, 'n allermagtigste rol gespeel.

Hierdie golf het die Angelsaksiese Metodisme ook verder krag. dadig voortgestu. P. W. Buys noem dit tereg die invalspoort van die geestelike imperialisme in Suid-Afrika. Maar tog gaan dit hier nie bloot om materialistiese Empirebelange nie. In die Angel-Saksiese wêreld was daar ' $n$ menigte opregte gelowiges wat gedryf is deur radikale millenialistiese verwagtinge. Die "Duisend-jarige ryk" was naby en dit was die roeping van die Engelse om dit te verhaas. $\mathrm{J}$. A. de Jongh beskryf dit volledig en gedokumenteerd in sy analise van Anglo-Amerikaanse sendingaksies in die tydperk van 16401810." As in die negentiende eeu (die vierde periode van J. $H$. Bavinck) die ,korte front” van die Piëtisme van die derde periode uitbrei verflou hierdie millenialistiese toekomsverwagtings en word vervang deur 'n meer wêreldse Christelike kultuurutopie. Ten spyte van sy dwalings en tekortkominge besiel dit derduisende Christene weer om die ganse wêreld in te trek en die Evangelie aan alle nasies en volke te gaan verkondig. Die eienaardige is dat die Metodiste en Metodisme hulle en sigself telkens weer totaal aanpas en inpas en met nuwe entoesiasme voortgaan en volhou. Die twintigste eeuse twee ontnugterende Wêreldoorloë het hierdie mensverankerde kultuuroptimisme miskien 'n dodelike wond toegedien, maar ten diepste nog nie vernietig nie. Watter rol die Metodisme in die laattwintigste eeu gaan speel weet ons nou nog nie. Dit het egter 'n geweldige rol in die agtiende en negentiende ceue, selfs tot byna 
die helfte van die twintigste ceu, gespeel. As die uittredende Aartsbiskop van Kantelberg, dr. Michael Ramsay, kan verklaar dat dit nic verkeerd is dat sy kerk op die aandelebeurs belê nie, mits dit nie in bier, wapens en Suid-Afrika is nie, omdat lg. dric die vernaamste sondes is, dan klink dit helaas baie na 'n "metodistiese" rangskikking van sondes. ${ }^{12}$

\section{Persoonlike Bybelverankerdheid}

Arminianisme, oplewings en imperialisme kan egter nie alles verklaar nie, veral nie die goeie van en in die Metodiste en Metodisme nie. Ons meen dat dit daarin geleë is dat elke gelowige telkens weer persoonlik teruggebring is na die Skrif en tot 'n groot mate daar gehou is, en daarom daaruit geleef, gewerk en geoffer het. Dit is interessant en van belang dat Latourette aantoon dat die RoomsKatolieke sendelinge deur die eeue heen meestal mense van die adel van hulle land was, en dat daarteenoor die Protestantisme sy sendingkragte meestal uit die sg. laere sosiale stande verkry het. Dit is miskien die kernkrag van die Metodisme dat dit die gewone man, ,the man in the street”, kon mobiliseer en aktiveer deur hom te leer om elke dag persoonlik-direk uit die Bybel te leef. „The universal priesthood of all men", die amp van die gelowige soos ons dit noem, is hier tot ontplooiing gebring op weergalose wyse. Dit is gedoen met beklemtoning van die daaglikse leiding van die Heilige Gees, iets wat ook dikwels tot gevaarlike en sondige uitwasse aanleiding gegee het, maar wat tog op sigself in sy suiwerheid, saam met die Woord nie anders as 'n krag ten goede kon wees nie. Hierin was en is die Metodisme nie uniek nie: die Hervorming het reeds die Bybel na die volk in eie taal gebring en daarmee die volk na die Bybel, en in die negentiende eeu is dit 'n kenmerk van al die Vrye Kerke (soos Algra dit noem) wat ontstaan o.a. deur afskeiding (of herstigting) van die gevestigde kerke, wat meestal staatskerke was. Barrett ${ }^{13}$ wys oortuigend daarop watter belangrike rol dit in die lewe van Bantoevolke in Afrika speel as hulle sover kom om die hele Bybel in eie moedertaal te kan kry en lees. Ook hier lei dit dan dikwels tot afskeiding van die gevestigde sendelingkerke.

Deurdat elke lidmaat daagliks onder leiding van die Heilige Gees, deur sy Metodistiese vereniging reëlmatig, byna militêragtig, geoefen word om met die Bybel om te gaan, is 'n baie doeltreffende Christelike leërmag gekweek. Waar dit by baie ander bewegings en rigtings tot wilde sektarisme en asketiese mistisisme ontaard het, is hierdie uitwasse miskien by die Metodisme getemper deur Wesley se uiters metodiese en sistematiese organisasie. Hierin was hy doodnugter en uiters doeltreffend en het hy self mettertyd 'n groot verenigingsleier geword. Later gebeur dit met genoemde John R. Mott ook. Albei was wêreldleiers, organisatories en geestelik en veral deur hulle geskrifte. Aan die een kant het Wesley se vereniging-isme die Kerk en instituut tot 'n groot mate verkrag en vermenslik, maar aan die ander kant het hierdie organisasiemetode, veral sy "classes", 'n soort kerklike of godsdienstige volwasse-onderwys vir die volkmassas gebied wat hulle gemobiliseer 
het. Die direkte Skrifkennis van elke lidmaat het daarby gedeeltelik sok gedien as korrektief op die mense se denke en handele, want die Woord van God keer tog nooit ledig terug nie. Daarom is dit moontlik dat hierdie mense, ten spyte van hulle offisiële Arminianisme, Revivalisme en imperialisme, tog dikwels die Evangelie in waarheid en krag uitgedra het. Ons dink hier aan die analoë uitspraak van Calvyn dat daar in die Rooms-Katolieke Kerk tog ten spyte van dié Kerk se dwaling goeie en waaragtige Christene en selfs plaaslike kerke mag wees.

Hierdie volksmobilisasie van die Metodiste was nie net tot die terrein van godsdiens in engere sin beperk nie. Totius sê: „Eers in die sewentiende eeu en verbonde aan die name van Puritein en Dissenter, Presbiteriaan en Independent het by die ware teelt van die Reformasie die potensies van die kerkhervormende, volkskerstende, statebouende beginsel openbaar geword". ${ }^{14}$ Hierop het die Metodiste o.a. baie doeltreffend voortgebou in die $18 \mathrm{e}$ en $19 \mathrm{e}$ eeue, ook buite die kerklike lewe. Beide Latourette en Algra wys elk op eie manier en vanuit eie gesigspunt daarop.

lemand het ergens geskryf dat dit opvallend is dat alle Primitivistiese bewegings besonder sterk en doeltreffend optree in die sendingveld. Daarteenoor vind ons dat kerke met 'n hoogsontwikkelde teologie dikwels baie flou die sendingbevel gehoorsaam. Hierdie sg. Primitiviste is mense wat onverbiddellik teruggaan na die ou Kerk, in die eerste eeue na Christus. Dit wou Wesley hulle ook doen - soos volledig deur Totius aangedui. Aan die een kant is dit korrek: Kerk en lidmaat moet elke dag teruggaan na die kinderlike begin, die ,primitiewe”, direk-persoonlike ontluiking van die geloof. Daarsonder sweef die mooiste en rykste kerklike lewe en teologie steriel in die lug. Dit is egter hoegenaamd nie voldoende nie. Die Bybel leer ons ook baie duidelik dat ons in die geloof moet groei en dat die kerk moet ontwikkel; daar mag nie by melkkos gestaan word nie, dan tree die radikaalste vorm van geestelike dood in (1 Kor. 3 en veral Hebr. 6).

Wat dit betref het die Metodiste en Metodisme aanvanklik doelbewus en volledig op die kerk as instituut, soos dit in Engeland bestaan het, eintlik geparasiteer. Wesley wou om die dood nie afskei nie en het aanvanklik sy hele organisasie ingepas in die bestaande kerklike tydtafel. Dit kon egter onmoontlik só bly voortgaan en uiteindelik was hy verplig om tot eie kerkstigting oor te gaan. In baie gevalle loop dit daarop uit dat die Metodistiese kerke ook selfs die biskoplike stelsel aanvaar en toegepas het, aanvanklik met skynbaar goeie resultate. Uiteindelik het hierdie kerke presies daar beland waar die Engelse Kerk gestaan het op die tydstip toe Wesley teen die doodsheid begin reageer het. Op die patroon raak hulle tot ' $n$ groot mate beide volk en Skrif kwyt. Uiteindelik loop dit uit in 'n noue identifikasie van kerk en staat, soos by die huidige Wêreldraad van Kerke wat netsoos die Pous graag beide swaarde (dié van die gees en dié van staal) hom wil toeëien en dit orals wil gebruik. Goddank is dit by verre nie die enigste ontwikkelingsrigting in die moderne Christendom nie. Latourette toon oortuigend aan dat ons 
orals, d.w.s. in die Protestantisme, Rooms-Katolisisme en Ortodoksisme gekom het by die toestand wat ons, in eie woorde, sou kon beskryf as die tydperk van post-staats- en post-volkskerk. Hy noem dit die vervanging van die gedagte en praktyk van die Corpus Christianum met dié van Corpus Christi, die Kerk as liggaam van Christus. ${ }^{15}$

Die amp van dic gelowige (art. $28 \mathrm{NGB}$ ) is nie net om in die binnekamer die Bybel te lees en om die leiding van die Heilige Gees te bid nie, maar ook om hom by die ware kork te voeg en van die valse kerk af te skei. Die kerk moet gebou word. Dit kan nie net uit fondamente bestaan nie, maar moet kom tot die volheid van die nuwe Jerusalem, wat netso hoog is as wat dit breed en lank is (Openb. $21: 16$ ). Hierin het die Metodisme tragies te kort geskiet en daarom sal die eertydse magtige wêreldbeweging versand en verloop tot tydelike, sporadiese en betreklik-futiele opwekkingsaksies.

In Engeland ${ }^{16}$ worstel die Metodiste Kerk saam met ander om voort te bestaan as instituut. In Suid-Indië het dit met ander kerke verenig. Die tyd dat ' $n$ man soos Mott drie keer na mekaar voorsitter en leier van wêreldsendingferensies kon wees, is skynbaar verby. Die verval wortel miskien grootliks in Wesley se dubbelslagtige standpunt ten opsigte van die kerk-as-instituut, die verplettering van die eertydse mensverankerde optimisme deur die twintigste eeuse twee Wêreldoorloë, opgevolg deur die hedendaagse grusame revolusie en terrorisme.

\section{Tekorte van die Metodisme, die korrektief}

In die drie artikels in genoemde „Revival” of „Reformasie” word volledig ingegaan op die tekortkominge van die Metodisme (aangevul met bestaande opmerkings van my, DM). Dit is interessant om Wesley self ook hier aan te haal. Kelley ${ }^{17}$ noem dit Wesley's Law: „wherever riches have increased, the essence of religion has decreased in the same proportion. Therefore I (Wesley) do not see how it is possible, in the nature of things, for any revival to continue long. For religion must necessarily produce both industry and frugality, and those cannot but produce riches. But as riches increase, so will pride, anger and love of the world in all its branches... Is there no way to prevent this ... continual decay of pure religion".

Hierop sou ons kon antwoord: op hierdie sondige aarde is daar geen sodanige metode nie. Die Kerk is helaas altyd blootgestel aan deformasie. Dit leer die Skrif van die begin af en veral in die briewe aan die sewe gemeentes in Klein Asië (Openb. 2 en 3). Dit bevestig ook dat ons selfs die jong kerk, van die na-apostoliese tyd nie as volmaakte model kan neem nie. Die repristinasie van Wesley en die syne is dus mis, al is dit hoe goed bedoel. Die volmaaktheid lê in die toekoms, op die nuwe aarde vanuit die nuwe hemel. Dit kom uiteindelik finaal van God Self. Hy onthef egter nie die mens, die gelowige volk van God, van hulle verantwoordelikheid en roeping tot reformasie nie. Net soos ons in liturgiese sake nie in trurat die na-apostolisme kerk mag veridealiseer nie, ${ }^{18}$ 
netso moet ons in dic hele lewe van die Kerk in al sy aspekte vorentoe kyk na dic voleinding en daarby die godgegewe erfenis vanuit die verlede gebruik. Die Metodisme wil net 'n sekere stukkie erfenis behou en alles wat onder leiding van die Heilige Gees deur eeue heen gegroei het verbygaan. Juis op die sendingvelde waar nuwe kerke geplant moet word, moet in albei blikrigtings na vore en na agter, ten volle met heldersiende geloof gekyk word. Daar moet steeds besef word dat ons leef en werk tussen die groot pole van volmaakte skepping, sondeval, kruis en opstanding van Christus, uitstorting van die Heilige Gees en uiteindelik volmaakte voleinding. Dit is miskien dié groot talent en prestasie van die Metodisme dat dit die gelowige by die Bybel gebring en daaruit laat leef het. Maar soos ook reeds gesê is dit nie voldoende nie. Wesley het skynbaar self besef soos hierbo aangehaal dat dit nie voldoende is nie. Die korrektief is om die hele, volle warheid van die Skrif in alle op. sigte te laat geld, ook soos dit uitgebou is in die konfessie deur die eeue heen. Die Skriftuurlike waarhede van verbond en uitverkiesing moet juis in die moderne tyd in die sendingwerk van die Kerk tot hulle reg kom, soos ons elders uitvoerig probeer uitwerk het. ${ }^{19}$ Die Kerk is die gesondene van Christus, en Hy van die Vader. Om onder leiding van die Heilige Gees sy taak te kan volvoer, moet die Kerk waaragtig Kerk bly en steeds meer en meer Kerk word. Liggaam van Christus en ook Bruid van die Lam van God. Die Kerk kan nie staatskerk of volkskerk wees sonder om sy eieaard in te boet nie. Maar dit kan ook nie 'n blote menslike vereniging word nie.

Ons geregverdigde kritiek op die Wesleyane se vereniging-isme sluit nie waardering uit vir die reedsgenoemde feit dat dit in sekere sin die amp van die gelowige besonder geaktiveer het nie. Van deurslaggewende belang is dat dit die individuele Christen geleer het om persoonlik uit eie sak, vrywillig, by te dra vir die saak van die Here. Latourette wys daarop hoe 'n magtige stroom geld vanaf die gewone man oor die wêreld gevloei het ter wille van die Evangelie, veral uit Noord-Amerika, waar die Europese staatskerke heel gou nie meer staatskerke was wat van staatsbelasting kon leef nie. Al het die Metodiste die skeppingsvolmaaktheid en die kultuurroeping van die mens in beginsel eintlik gladnie in Bybelse sin raakgesien nie en nooit bewus-verantwoord erken nie (vgl. bostaande aanhaling van Wesley self), het hulle tog die hele wêreld vol skole, selfs universiteite en hospitale gebou (meestal op die sendingveld) met vrywillige, persoonlike bydraes van individuele Christene. As Wesley die skepping en Bybelse kultuurroeping raakgesien het, sou hy besef het dat die ware godsdiens nie net 'n kwessie van armwees is nie, maar dat die ryke en die arme albei rentmeesters van God is met alles wat hulle besit en verkry op aarde. Netsoos daar armes is wat God vloek, is daar deur sy genade rykes, soms geslagte na mekaar, wat Hom getrou en gehoorsaam dien uit dankbaarheid.

As die kerk volledig en vol op die hele Skrif gaan staan en voortwerk in sy gesondenheid, dan sal dit vorder sonder die bykomstige "hulp" van Arminianisme, oplewings en imperialisme en steeds daartoe bydra dat beide ou en nuwe kerke steeds meer en 
meer en suiwerder waaragtig en net Kerk sal wees, Corpus Christi, die liggaam van Christus en tegelyk Bruid van die Lam, 'n ligtende lig en 'n soutende sout in hierdie moderne sondige wêreld. Selfs op hierdie suiwere fondament, sal die kerk voortdurend die stryd teen die sonde, ook in eie boesem, moet stry en alleen daarin kan oorwin deur die Woord en Gees van God en sy genade en barmhartigheid in Jesus Christus.

Prof. D. C. S. van der Merwe.

\section{AANTEKENINGE:}

1 Lange, J. P.: Das Evangelium Markus, p. 106; Van Oosterzee. Das Evangelium Lukas, p. 215 en verder - albei in Theol.hom. Dibelwerk, red. J. P. Lange, 5e uitgawe, Leipzig, 1902. Cole, A.: Mark, p. 151. Tyndale N. T.: Commentaries, red. R.V. Tasker, London, 1969.

2 Du Toit, J. D.: Versamelde Werke, deel viii, Johannesburg, 1962. Die Metodisme, p. $1 \neq 3$.

3 Van der Merwe, D. C. S.: Sending, toekoms en strukture, Pro Rege, Potchefstroom, 1974 , p. 17.

4 Latourette, K. S.: A History of the Expansion of Christianity, 7 dele, 1970. Christianity in a Revolutionary Age. Verder: Algra, H.: Het Wonder van de negentiende eeuw van vrije kerken en klein luyden. Franeker, T.: Wever, 1965 of 1966. Bates, H. S. en Pauch, W. (red.): The Prospects of Christianity throughout the World. New York, Scribher, 1964. Neill, S.: A history of Christian Missions. Hodder on Stoughton, 1965. Du Plessis, J. A.: History of Christian Missions in S.A., Kaapstad, Struik, 1965. Gerdener, G. B. A.: Recent Developments in the S.A. Mission Field, Pretoria, N.G. Kerk Uitgewers, 1958. Christelijke Encyclopedia: The Oxford Dictionary of the Christian Church. Bavinck, J. H.: Inleiding in de Zendingwetenskap. Kampen, Kok, 1954.

5 Bavinck, J. H.: a.w., p. 302.

6 Du Toit, J. D.: a.w., p. 57-62.

7 Van der Waal, C.: Antithese of Synthese. De Oecumenishe beweging beschreven en getoets. Enschede, J. Boersma, 1951.

8 Latourette: Expansion, IV, p. 185.

9 Die feit haal ons aan uit 'n onlangse SAUK radiopraatjies-reeks.

10 Spoelstra, B.: Kolonialisme en ons sendingkrisis gedurende die vorige ceu. In: Die Saailand is die Wèreld, Hammanskraal, 1973.

11 De Jongh, J. A.: As the waters cover the sun. Millenial expectations in the rise of the Anglo-America missions 1640-1810. Kampen, Kok, 1970.

12 Die Transvaler, $275,74$.

13 Barret, D. B.: Schism and Renewal in Africa, Nairobi, Oxford Univ. Press, 1968.

14 Du Toit, J. D.: a.w., p. 28.

15 Latourette: a.w. Expansions, VII, p. 413.

16 Botes, a.w.

17 Read, W. R. and Ineson, P. A. (red.): Brasil 1980. The Protestant Handbook. NARC, Monrovia, California, 1973; p. 48 en voetnoot.

18 Van der Merwe, D. C. S.: Twintigste Eeuse Liturgiese Vernuwing. Potchefstroom, Pro Rege, 1973.

19 Sending en Uitverkiesing. Die Kerkbladkantoor, Potchefstroom 1960.

Verbond en Sending. Die Kerkbladkantoor, Potchefstroom 1965. 